\title{
Snail Mucus From the Mantle and Foot of Two Land Snails, Lissachatina Fulica and Hemiplecta Distincta, Exhibits Different Protein Profile and Biological Activity
}

\section{Nattaphop Noothuan}

Chulalongkorn University Faculty of Science

Kantamas Apitanyasai

Chulalongkorn University Faculty of Science

Somsak Panha

Chulalongkorn University Faculty of Science

Anchalee Tassanakajon ( $\square$ anchalee.k@chula.ac.th )

Chulalongkorn University Faculty of Science

\section{Research note}

Keywords: land snail, snail mucus, antimicrobial activity, anti-tyrosinase activity, antioxidant activity

Posted Date: March 22nd, 2021

DOl: https://doi.org/10.21203/rs.3.rs-322293/v1

License: (a) (i) This work is licensed under a Creative Commons Attribution 4.0 International License.

Read Full License

Version of Record: A version of this preprint was published at BMC Research Notes on April 15th, 2021. See the published version at https://doi.org/10.1186/s13104-021-05557-0. 


\section{Abstract}

Objective: Snails secrete different types of mucus that serve several functions, and are increasingly being exploited for medical and cosmetic applications. In this study, we explored the protein pattern and compared the biological properties of the mucus secreted from the mantle collar and foot of two snail species, Lissachatina fulica and Hemiplecta distincta.

Result: Protein profile showed a different pattern between the two species and between the two secretory parts. The mantle-specific protein bands were further characterized and among them was an antibacterial protein, achacin. Accordingly, the mucus from the mantle exhibited the higher antibacterial activity than that from the foot in both snail species. The mucus from $\mathrm{H}$. distincta, first reported here, also showed antibacterial properties, but with a lower activity compared to that for L. fulica. Snail mucus also exhibited anti-tyrosinase activity and antioxidant activity but with no significant difference between the foot and mantle mucus. These results indicate some different protein compositions and biological activities of snail slime from the mantle and foot, which might be associated with their specific functions in the animal and are useful for medical applications.

\section{Introduction}

Land snails have been used as food and for various medical treatments for centuries [1-3]. The snail slime (mucus) has many functions in the animal, such as adhesive, emollient, moisturizing, lubricant, and defense [4-7]. Recently, snail slimes have been applied in human medical and cosmetics [8-11]. Studies have shown that snail mucus exhibits various biological activities, such as antimicrobial, antioxidant, anti-tyrosinase, and antitumoral activities $[10,12,13]$. In addition, many compounds have been found in snail mucus, such as allantoin, hyaluronic acid, peptides and proteins $[3,4,14]$. Moreover, it has been reported that different kinds of mucus are released from the different types of secretory glands in a snail, depending on the way it is stimulated [15]. However, little work on the biochemical properties that give rise to these functional differences has been elucidated.

In this study, the mucus was collected from the mantle and foot of two snail species, $\mathrm{H}$. distincta and $L$ fulica, in which $H$. distincta is distributed in deciduous forest in Thailand [16], but L. fulica is a very famous invasive alien species that occurring everywhere at anthropogenic areas in many parts of the world [17]. The protein pattern and biological properties (antioxidant, antibacterial, and anti-tyrosinase activities) of the mucus were then compared.

The results revealed somewhat different protein compositions and biological properties (antimicrobial activity, anti-tyrosinase activity, and antioxidant activity) that are probably associated with their functions and are useful for cosmetic and medical applications.

\section{Materials And Methods}

\section{Sample preparation}


Two species of land snail, L. fulica and $\mathrm{H}$. distincta, were collected from the wild in Thailand. The snails ( $n=20$ each species/anatomical location) were reared at $24^{\circ} \mathrm{C}$ for 2 days. then, the mucus was extracted by gently poking on foot and mantle lobes. The harvested mucus was filtered through $0.45-\mu \mathrm{m}$ membrane (Millipore) and stored at $4{ }^{\circ} \mathrm{C}$ before use. This process did not harm the snails and the experiments was carried out in accordance with the approved guidelines of the Animal Care and Use Committee of Faculty of Science, Chulalongkorn University (Protocol Review No. 1223003).

Escherichia coli ATCC 25922, Bacillus subtilis ATCC 6633, and Acinetobacterspp. L9, PK3, and Y3 were cultured in Luria-Bertani broth at $37^{\circ} \mathrm{C}$, while Staphylococcus aureus ATCC 25923 was cultured in tryptic soy broth with $2 \%(\mathrm{w} / \mathrm{v}) \mathrm{NaCl}$ at $30{ }^{\circ} \mathrm{C}$ with shaking overnight. The bacteria were re-inoculated in the fresh media and cultured until they reached $\mathrm{OD}_{600}$ of 0.2 and were diluted about hundred-fold in poor broth $[1 \%$ $(\mathrm{w} / \mathrm{v})$ tryptone, $0.5 \%(\mathrm{w} / \mathrm{v}) \mathrm{NaCl}, \mathrm{pH} 7.5$ ] to an $\mathrm{OD}_{600}$ of 0.001 . the selected bacteria are prevalent species of gram negative and positive bacteria and most common nosocomial pathogens.

\section{SDS-PAGE and LC-MS/MS}

The protein concentration of slime was determined using the Bradford assay [18], and then $25 \mu \mathrm{g}$ of the sample was mixed with $5 \mathrm{X}$ reducing SDS loading dye and heated at $100^{\circ} \mathrm{C}$ for $10 \mathrm{~min}$. The samples were then subjected to $12.5 \%$ SDS-PAGE. One gel was stained with Coomassie blue and the other gel was developed by silver staining [19].

The selected protein bands were cut from the stained SDS-PAGE and analyzed using LC-MS/MS at the Research Instrument Center, Khon Kaen University, Thailand. Briefly, the protein bands were destained, reduced, and digested with Sequencing Grade Modified Trypsin. The tryptic peptides were extracted and analyzed using LC-MS/MS. The obtained data were searched in Protein database using the MASCOT program.

\section{Antimicrobial activity assay}

The antimicrobial activity of snail mucus was analyzed using the minimal inhibitory concentration assay [20]. The snail mucus $(12.5,25,50,100$, and $200 \mu \mathrm{g}$ of total protein in $100 \mu \mathrm{l}$ phosphate-buffered saline (PBS) $)$ was added and then inoculated with $20 \mu$ of the fresh bacterial culture $\left(1 \times 10^{4}\right.$ cells, $\mathrm{OD}_{600}=$ $0.001)$. The reactions were incubated overnight and then the bacterial growth was measured at $\mathrm{OD}_{600}$. The negative controls were performed using PBS.

\section{Anti-tyrosinase activity assay}

Each $25-\mu \mathrm{g}$ total protein of mucus adjusted with PBS to $70 \mu \mathrm{l}$ was incubated with $10 \mu \mathrm{l}$ of mushroom tyrosinase (Sigma-Aldrich) in potassium phosphate buffer pH 6.5 (5 U/reaction), and then $20 \mu \mathrm{l}$ of 1 $\mathrm{mg} / \mathrm{ml}$ L-DOPA (Sigma-Aldrich) in buffer was added. The reactions were monitored the absorbance at $A_{475}$. Distilled water was used as a negative control and kojic acid as positive control. The inhibition was calculated from the formula: Inhibition $(\%)=\left[1-\left(A_{475}\right.\right.$ in sample $/ A_{475}$ in control $\left.)\right] \times 100 \%$. 
A 100- $\mu$ l of the snail mucus in various concentration was added into the each well and incubated with $100 \mu$ of $0.2 \mathrm{mM} \mathrm{DPPH}$ in absolute ethanol in dark place for $30 \mathrm{~min}$. Then, the absorbance was measured at $517 \mathrm{~nm}\left(\mathrm{~A}_{517}\right)$ [21]. Distilled water was used as a negative control and ascorbic acid as a positive control. The DPPH scavenging effect was calculated by the following formula: \%Effective = $\left(A_{\text {Blank }}-A_{\text {Sample }}\right) / A_{\text {sample }} \times 100$. \%Effective were plotted against concentration by GraphPad Prism 8. The $\mathrm{EC}_{50}$ values were calculated as the concentration to cause half-maximal inhibition of DPPH radical scavenging.

\section{Statistical Analysis}

Results were represented as mean with standard deviation in triplicate. Statistical analysis was performed using a one-way analysis of variance (ANOVA) followed by Tukey's test. Significance was accepted at the $p<0.05$ level.

\section{Results}

\section{Snail mucus extraction and protein profiles}

The protein pattern of the two snails analyzed by $12.5 \%$ SDS-PAGE exhibited quite a different banding pattern despite some commons bands that were observed (Additional file1: Fig. S1). The L. fulica mucus showed major bands at about $13,37,70$, and $>200 \mathrm{kDa}$, whereas $H$. distincta showed major bands at approximately 11, 12, 14, 25, and $120 \mathrm{kDa}$ (Additional file2: Fig. S2).

\section{Protein pattern of snail mucus from the mantle and foot of $L$. fulica and $H$. distincta}

The snail mucus from the mantle collar and foot of $L$. fulica and $H$. distincta was separately collected and analyzed the protein profiles. The results showed common protein bands with some distinct bands (Fig. 1A). In addition, a gel with silver staining for $L$. fulica mucus was used to increase the sensitivity for detection of the mantle-specific bands, from which the band of about $30 \mathrm{kDa}$ was selected (Fig. 1B). It should be noted that the reproducibility of this protein pattern might be varied from each sample collection, seasonal and location so the major protein bands which was more consistently observed were selected for further analysis.

\section{Identification of selected proteins by LC-MS/MS}

The mucus from foot facilitates snail movement while the mantle mucus moistens the snail body, healing wounds and infections. Thus, for the purpose of medical and cosmetic applications, three distinct mantle-specific protein bands ( $30 \mathrm{kDa}$ and $60 \mathrm{kDa}$ from L. fulica and $56 \mathrm{kDa}$ from H. distincta), shown in Fig. 1, were subjected to further analysis by LC-MS/MS. The results, matched with different known proteins (Additional file3: Table S1) suggested that each band might be a mixture of proteins. Interestingly, the 30 and $60 \mathrm{kDa}$ proteins were matched with achacin, the antimicrobial peptide in L. fulica, 
while the 56 and $60 \mathrm{kDa}$ protein band from H. distincta and L. fulica, respectively, matched with different proteins including a sarcoplasmic calcium-binding protein (Scb).

\section{Biological activity of snail mucus}

\section{Antibacterial activity}

The antibacterial activity was tested against Gram-positive (S. aureus and B. subtilis) and Gram-negative (E. coli and Acinetobacter spp.) bacteria using a liquid broth inhibition assay. The mucus from the mantle of $L$. fulica exhibited antibacterial activity against all four tested bacterial strains while the mucus from the foot showed a lower activity against $E$. coli and B. subtilis only (Fig. 2). The mucus from the mantle of $H$. distincta could slightly inhibit $E$. coli and $B$. subtilis while the mucus from the foot has no antibacterial activity at the tested concentrations (Fig. 3). Overall, the results clearly demonstrated the higher antibacterial activity of the mucus from the mantle than that from the foot in both snail species.

\section{Anti-tyrosinase activity}

The $L$. fulica mucus had a significantly higher tyrosinase inhibition activity (32.3\% and $33.4 \%)$ than the $H$. distincta mucus ( $14.7 \%$ and $16.5 \%$ ) for both the mantle and foot mucus, respectively but the antityrosinase activity of the mantle and foot mucus was not significantly different within a species for both snail species.

\section{Antioxidant activity}

The mucus from both snails showed an antioxidant activity, with a lower $\mathrm{EC}_{50}$ found in the mucus of $L$. fulica. The mantle mucus from $H$. distincta had a significantly higher $\mathrm{EC}_{50}(\mathrm{mg})$ of $129.9 \pm 15.9$ (less active) than that of the mantle $94.5 \pm 4$.3. For $L$. fulica, the $\mathrm{EC}_{50}(\mathrm{mg})$ between the foot $(25.5 \pm 2.9)$ and mantle $(27.8 \pm 5.2)$ were not significantly different.

\section{Discussion}

It has previously been shown that different types of secretory glands discharge slime on to the surface of the mantle collar and foot of Helix aspersa [15]. As the slime performs various functions in the life of the snails, it is likely that snail slime compositions would vary according to the functional demands [22]. In this study, we found distinct protein patterns between the foot and mantle mucus within the same species and between the two different species of L. fulica and $H$. distincta.

For the purpose of medical and cosmetic uses, the mantle-specific protein bands were selected for further analysis by LC-MS/MS. Interestingly, one of the proteins identified from the selected distinct bands that was only observed in the L. fulica mantle mucus matched to achacin, an antibacterial protein [23-25]. This might reflect the strong antibacterial activity of $L$. fulica mantle mucus against all four tested bacteria, while the mucus from the foot that lacked this protein band could inhibit only the growth of $E$. coli and S. aureus. Previous studies have reported that the mucus from L. fulica and $H$. aspersa exhibited 
antibacterial activity against various strains of bacteria and fungi [26-30]. Moreover, several antimicrobial peptides (AMPs) from L. fulica mucus and $H$. aspersa have been investigated [25, 31-34]. Recently, the crude protein extracted from six snail species also showed antimicrobial activity against some bacteria and fungi [12].

Achacin is an antibacterial glycoprotein from the body surface mucus of $L$. fulica, which has been shown to exhibit a bactericidal effect [35]. In addition, the cDNA of achacin precursor was successfully cloned from the tissue of the snail collar [36]. Our study demonstrated that the mantle mucus of L. fulica may contain a higher relative activity of achacin than the foot mucus (which may contain none). The two bands of 60 and $30 \mathrm{kDa}$, identified as achacin suggest that the protein might function as a multi-subunit protein [15] or be in different states of glycosylation, etc. In this study, we also report for the first time the antimicrobial activity of the snail mucus from $\mathrm{H}$. distincta but further investigations are needed to identify the antimicrobial molecule(s).

Related to the function of the mantle, the LC-MS/MS analysis also identified a mantle-specific protein band as a Scp, which was also not detected in the foot mucus. The mantle is muscular and forms the outer wall of the snail's body and secretes a mucus that contains a calcium-binding protein, which probably participates in the formation of calcium carbonate crystals to repair and maintain the shell of snail [37].

It has been shown that snail mucus from $H$. aspersa could inhibit the tyrosinase activity and melanin production on cell lines $[11,14]$. In other snails, the extracts from different parts showed an antioxidant activity and the presence of many bioactive compounds [38-41]. In this study, we showed that the snail mucus from both $L$. fulica and $H$. distincta also exhibited an anti-tyrosinase as well as antioxidant activity. The biological activities of snail mucus indicate the beneficial effect on therapeutic and cosmetic applications.

In summary, the mucus secreted from the mantle and foot of $L$. fulica and $H$. distincta exhibits somewhat different protein compositions and biological assays clearly demonstrated that the mantle mucus exhibited a higher antibacterial activity than the foot mucus in both snail species. Various compounds in snail mucus need to be further characterized and clarified for their functions in the animal and the proper use in various applications.

\section{Limitations}

Other components in the snail secretion besides proteins, were not analyzed in this study and they are likely to contribute also to the different biological activity of the snail secretion between foot and mantle.

\section{Abbreviations}

SDS-PAGE: Sodium dodecyl sulphate-polyacrylamide gel electrophoresis

LC-MS/MS: Liquid chromatography/tandem mass spectroscopy 
U: Unit

OD: Optical density

EC: Effective concentration

DPPH: 2,2'-diphenyl-1-picrylhydrazyl

L-DOPA: L-3,4-dihydroxyphenylalanine

\section{Declarations}

\section{Ethics approval and consent to participate}

Not applicable.

\section{Consent for publication}

All authors consent to the current version of the manuscript for submission.

\section{Availability of data and materials}

All raw data are available from the corresponding author upon request.

\section{Competing interests}

The authors declare that they have no competing interests.

\section{Funding}

This research was financially supported by The Thailand Research Fund, TRF-DPG628001, and the Center of Excellence on Biodiversity, BDC-PG1-159005.

\section{Author's contributions}

NN performed lab work, analyzed the data and wrote the draft manuscript. KA performed lab work and analyzed the data. SP supervised snail sample collection and experimental design. AT supervised protein analysis and biological activity, data analyses, and edited the paper. All authors read and approved the final manuscript.

\section{Acknowledgements}

We thank Dr. Robert Douglas John Butcher for English language corrections and critical reading and suggestion of this manuscript. We also thank Dr. Piyoros Tongkerd and the team for sample collection. 


\section{References}

1. Bonnemain B. Helix and drugs: snails for western health care from antiquity to the present. Evid Based Complement Alternat Med. 2005;2:25-8.

2. Meyer-Rochow VB. Therapeutic arthropods and other, largely terrestrial, folk-medicinally important invertebrates: a comparative survey and review. J Ethnobiol Ethnomedicine. 2017;13:9.

3. Cilia G, Fratini F. Antimicrobial properties of terrestrial snail and slug mucus. J Complement Integr Med. 2018;15.

4. Trapella C, Rizzo R, Gallo S, Alogna A, Bortolotti D, Casciano F, et al. HelixComplex snail mucus exhibits pro-survival, proliferative and pro-migration effects on mammalian fibroblasts. Sci Rep. 2018;8:17665-74.

5. Greistorfer S, Klepal W, Cyran N, Gugumuck A, Rudoll L, Suppan J, et al. Snail mucus - glandular origin and composition in Helix pomatia. Zool. 2017;122:126-38.

6. Adikwu M, Alozie BU. Application of snail mucin dispersed in detarium gum gel in wound healing. SRE. 2007;2:195-8.

7. Adikwu M, Enebeke TC. Evaluation of snail mucin dispensed in brachystegia gum gel in wound healing agent. Anim Res Int. 2008;4:685-97.

8. Truchuelo MT, Vitale M. A cosmetic treatment based on the secretion of Cryptomphalus aspersa $40 \%$ improves the clinical results after the use of nonablative fractional laser in skin aging. J Cosmet Dermatol. 2019;19:622-8.

9. Brieva A, Philips N, Tejedor R, Guerrero A, Pivel JP, Alonso-Lebrero JL, et al. Molecular basis for the regenerative properties of a secretion of the mollusk Cryptomphalus aspersa. Skin Pharmacol Physiol. 2008;21:15-22.

10. Fabi SG, Cohen JL, Peterson JD, Kiripolsky MG, Goldman MP. The effects of filtrate of the secretion of the Cryptomphalus aspersa on photoaged skin. J Drugs Dermatol. 2013;12 4:453-7.

11. Tribó-Boixareu MJ, Parrado-Romero C, Rais B, Reyes E, Vitale-Villarejo MA, Gonzalez S. Clinical and histological efficacy of a secretion of the mollusk Cryptomphalus aspersa in the treatment of cutaneous photoaging. J Cosmet Dermatol. 2009;22:247-52.

12. Ulagesan S, Kim HJ. Antibacterial and antifungal activities of proteins extracted from seven different snails. Appl Sci. 2018;8:1362.

13. Ellijimi C, Hammouda MB, Othman H, Moslah W, Jebali J, Mabrouk HB, et al. Helix aspersa maxima mucus exhibits antimelanogenic and antitumoral effects against melanoma cells. Biomed Pharmacother. 2018;101:871-80.

14. El Mubarak MA, Lamari FN, Kontoyannis C. Simultaneous determination of allantoin and glycolic acid in snail mucus and cosmetic creams with high performance liquid chromatography and ultraviolet detection. J Chromatogr A. 2013;1322:49-53.

15. Campion M. The structure and function of the cutaneous glands in Helix aspersa. Q J Microsc Sci. 1961;102:195-216. 
16. Sutjarit J, Jeratthitikul E, Tongkerd P, Panha S. Reassessment and systematic position of the sinistral snails of genus Hemiplecta from Thailand (Eupulmonata: Ariophantidae), with description of two new species. Contributions to Zoology. 2020;90:1-33.

17. Gołdyn B, Kaczmarek Ł, Roszkowska M, Ríos Guayasamín P, Książkiewicz-Parulska Z, Cerda H. Urban Ecology of Invasive Giant African Snail Achatina fulica (Férussac) (Gastropoda: Achatinidae) on its First Recorded Sites in the Ecuadorian Amazon. American Malacological Bulletin. 2017;35:5964.

18. Bradford MM. A rapid and sensitive method for the quantitation of microgram quantities of protein utilizing the principle of protein-dye binding. Anal Biochem. 1976;72:248-54.

19. Hames BD. Gel electrophoresis of proteins: a practical approach. 3 ed: Oxford University Press; 1998.

20. Wiegand I, Hilpert K, Hancock R. Agar and broth dilution methods to determine the minimal inhibitory concentration (MIC) of antimicrobial substance. Nat Protoc. 2008;3:163-75.

21. Shimamura T, Sumikura Y, Yamazaki T, Tada A, Kashiwagi T, Ishikawa H, et al. Applicability of the DPPH assay for evaluating the antioxidant capacity of food additives - inter-laboratory evaluation study. Anal Sci. 2014;30:717-21.

22. Denny M. Molecular Biomechanics of Molluscan Mucous Secretions. In: Hochachka PW, editor. Metabolic Biochemistry and Molecular Biomechanics: Academic Press; 1983. p. 431-65.

23. Kubota Y, Watanabe Y, Otsuka H, Tamiya T, Tsuchiya T, Matsumoto JJ. Purification and characterization of an antibacterial factor from snail mucus. Comp Biochem Physiol C Comp Pharmacol Toxicol. 1985;82:345-8.

24. Obara K, Otsuka-Fuchino H, Sattayasai N, Nonomura Y, Tsuchiya T, Tamiya T. Molecular cloning of the antibacterial protein of the giant African snail, Achatina fulica Férussac. Eur J Chem. 1992;209:16.

25. Otsuka-Fuchino H, Watanabe Y, Hirakawa C, Tamiya T, Matsumoto JJ, Tsuchiya T. Bactericidal action of a glycoprotein from the body surface mucus of giant African snail. Comp Biochem Physiol C Comp Pharmacol Toxicol. 1992;101:607-13.

26. Santana WA, Melo CM, Cardoso JC, Pereira-Filho RN, Rabelo AS, Reis FP, et al. Assessment of antimicrobial activity and healing potential of mucous secretion of Achatina fulica. Int $\mathrm{J}$ Morphol. 2012;30:365-73.

27. Etim L, Aleruchi C, Obande G. Antibacterial properties of snail mucus on bacteria isolated from patients with wound infection. Br Microbiol Res J. 2016;11:1-9.

28. Zodape GV. A study on presence of bioactive compounds in snail Achantina fulica. J Nat Appl Sci. 2010;2:266-8.

29. Bortolotti D, Trapella C, Bernardi T, Rizzo R. Letter to the Editor: Antimicrobial properties of mucus from the brown garden snail Helix aspersa. Br J Biomed Sci. 2016;73:49-50.

30. Pitt SJ, Graham MA, Dedi CG, Taylor-Harris PM, Gunn A. Antimicrobial properties of mucus from the brown garden snail Helix aspersa. Br J Biomed Sci. 2015;72:174-81. 
31. Ehara T, Kitajima S, Kanzawa N, Tamiya T, Tsuchiya T. Antimicrobial action of achacin is mediated by L-amino acid oxidase activity. FEBS Lett. 2002;531:509-12.

32. Mukherjee S, Barman S, Mandal NC, Bhattacharya S. Anti-bacterial activity of Achatina CRP and its mechanism of action. Indian J Exp Biol. 2014;52:692-704.

33. Zhong J, Wang W, Yang X, Yan X, Liu R. A novel cysteine-rich antimicrobial peptide from the mucus of the snail of Achatina fulica. Peptides. 2013;39:1-5.

34. Dolashka P, Dolashki A, Beeumen JV, Floetenmeyerd M, Velkova L, Stevanovic S, et al. Antimicrobial activity of molluscan hemocyanins from Helix and Rapana snails. Curr Pharm Biotechnol. 2016;17:263-70.

35. Iguchi SM, Aikawa T, Matsumoto JJ. Antibacterial activity of snail mucus mucin. Comp Biochem Physiol A Comp Physiol. 1982;72(3):571-4.

36. Ogawa M, Nakamura S, Atsuchi T, Tamiya T, Tsuchiya T, Nakai S. Macromolecular antimicrobial glycoprotein, achacin, expressed in a methylotrophic yeast Pichia pastoris. FEBS Lett. 1999;448:41-4.

37. Sullivan JT, Cheng TC. Structure and function of the mantle cavity of Biomphalaria glabrata (Mollusca: Pulmonata). Trans Am Microsc Soc. 1974;93:416-20.

38. Purwaningsih S, Handharyani E, Ananda WAR. Hepatoprotective activity of mangrove snail (Telescopium sp.) extract in sprague dawley rats induced by paracetamol. IOP Conf Ser Earth Environ Sci. 2019;241:012022.

39. Petsantad P, Sangtanoo P, Srimongkol P, Saisavoey T, Reamtong O, Chaitanawisuti $\mathrm{N}$, et al. The antioxidant potential of peptides obtained from the spotted babylon snail (Babylonia areolata) in treating human colon adenocarcinoma (Caco-2) cells. RSC Adv. 2020;10(43):25746-57.

40. Lawal B, Shittu OK, Ossai PC, Asmau AN, Ibrahim AM. Evaluation of antioxidant activity of giant African snail (Achachatina maginata) haemolymph in CCl4-induced hepatotoxixity in albino rats. $\mathrm{Br}$ J Pharm Res. 2015;6:141-54.

41. Matusiewicz M, Kosieradzka I, Niemiec T, Grodzik M, Antushevich $\mathrm{H}$, Strojny B, et al. In vitro influence of extracts from snail Helix aspersa Müller on the colon cancer cell line Caco-2. Int J Mol Sci. 2018;19:1064.

\section{Figures}


(A)

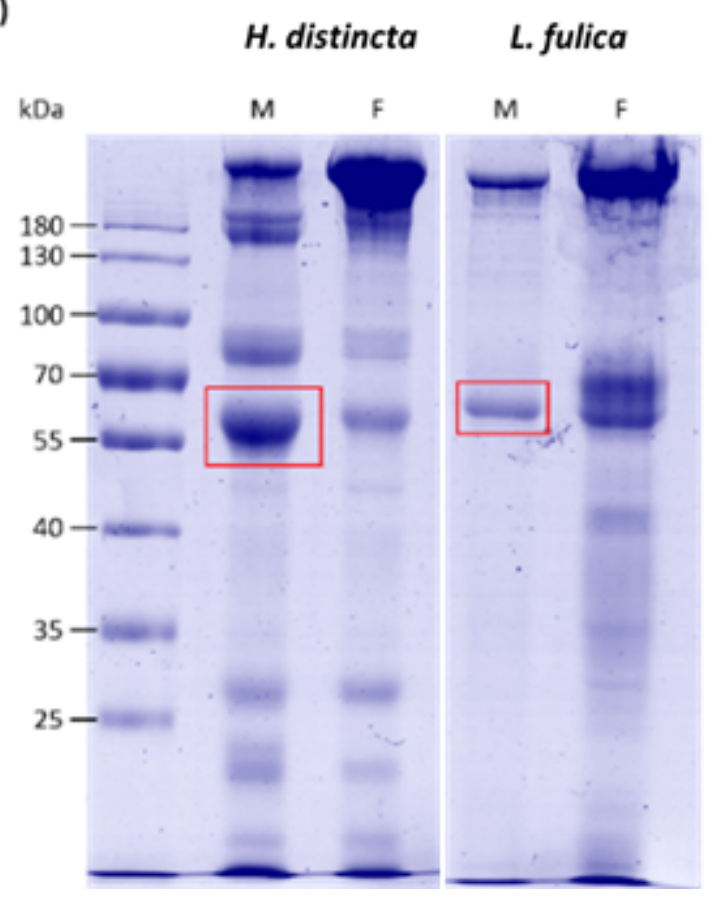

(B)

\section{L. fulica}

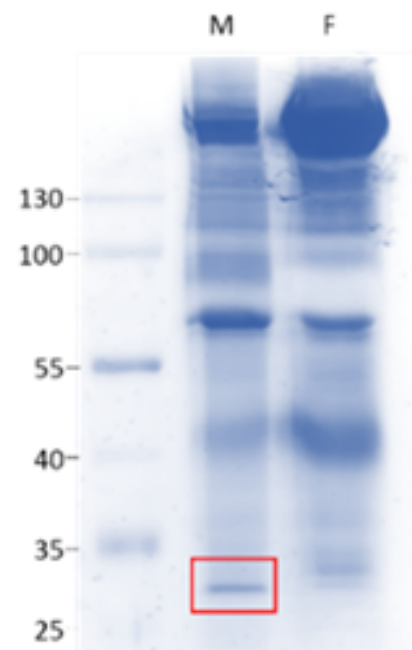

25

\section{Figure 1}

Analysis of the protein pattern in snail mucus from the mantle $(M)$ or foot $(F)$ of $L$. fulica and $H$. distincta by SDS-PAGE. A total protein content of $25 \mu \mathrm{g} /$ lane was subjected to $12.5 \%$ SDS-PAGE and stained with (A) Coomassie Brilliant Blue or (B) silver staining. The red box indicates distinct protein bands that were chosen for further analysis. Prestain marker PageRuler was used for size estimation. 
E. coll

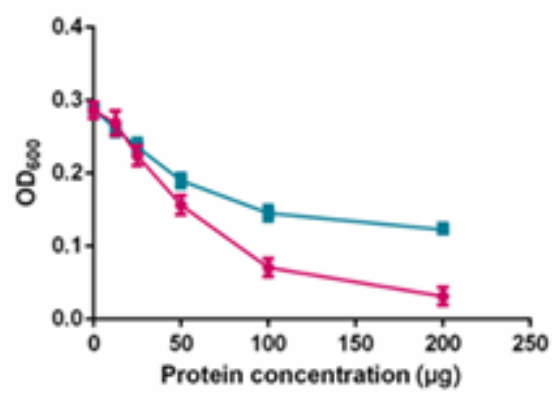

S. aureus

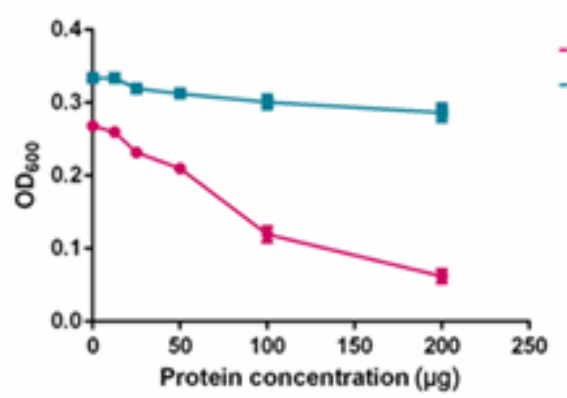

Acinetobacter sp. PK3

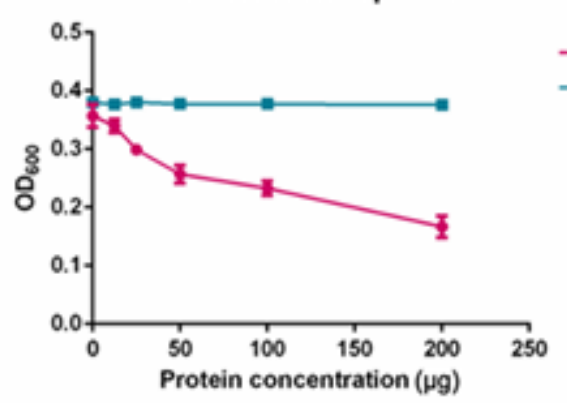

B. subtilis

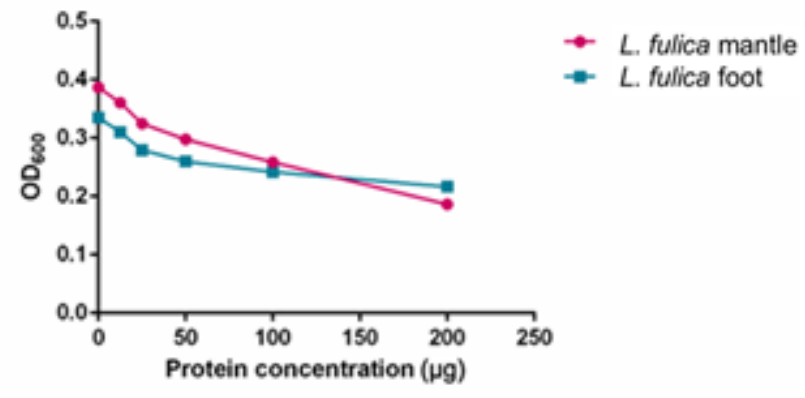

Acinetobacter sp. L9

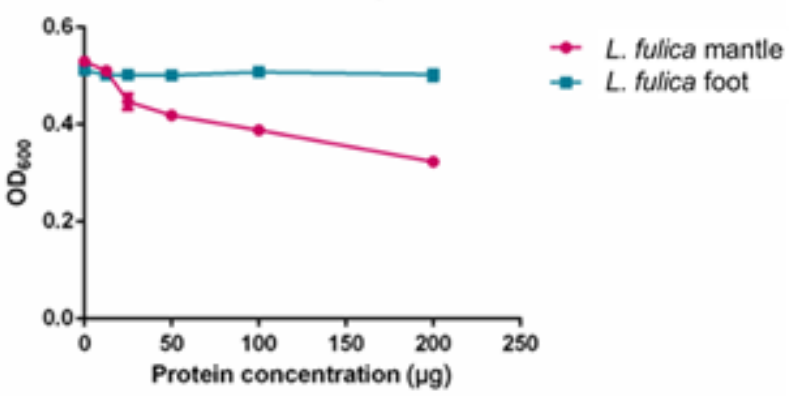

Acinetobacter sp. Y3

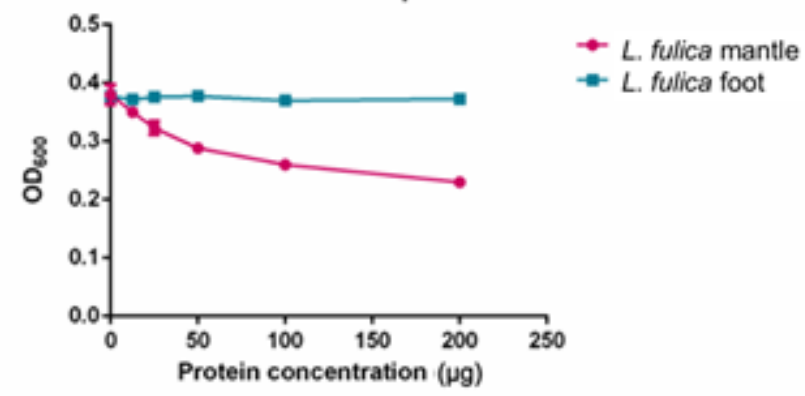

Figure 2

Antibacterial activity of L. fulica mucus. The different protein concentrations $(12.5,25,50,100$, and 200 $\mu \mathrm{g} / 100 \mu \mathrm{l}$ PBS) were incubated with E. coli, B. subtilis, S. aureus, and Acinetobacter sp. L9, PK3, and Y3 overnight and then the OD600 was determined. Data are shown as the mean \pm standard deviation, derived from three independent replicates. 
E. coli

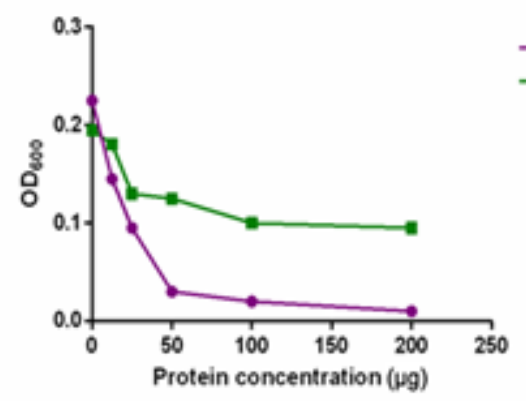

S. aureus

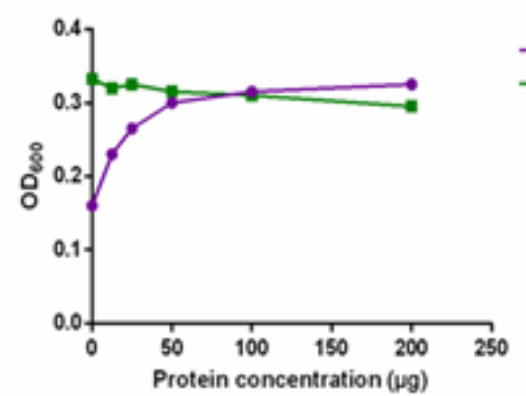

Acinetobacter sp. PK3

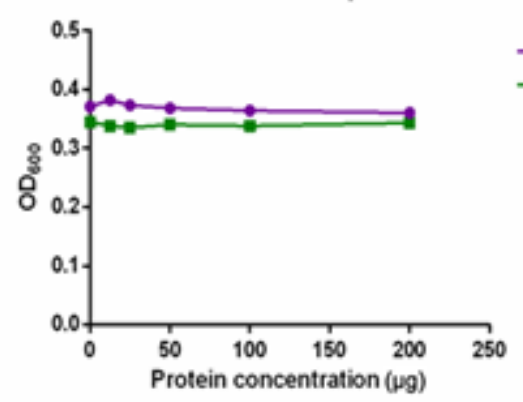

B. substilis

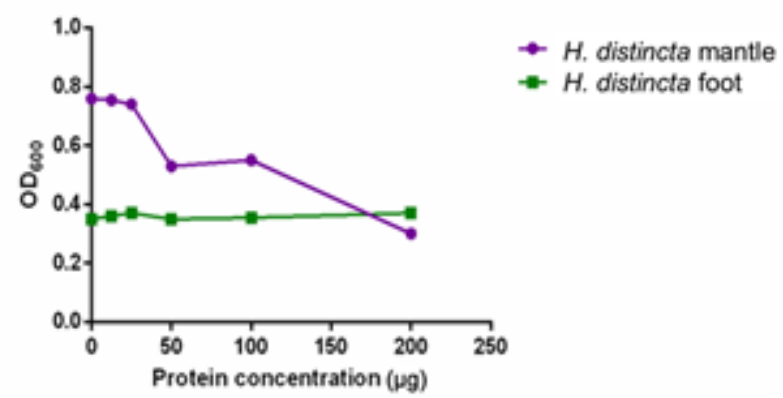

Acinetobacter sp. L9

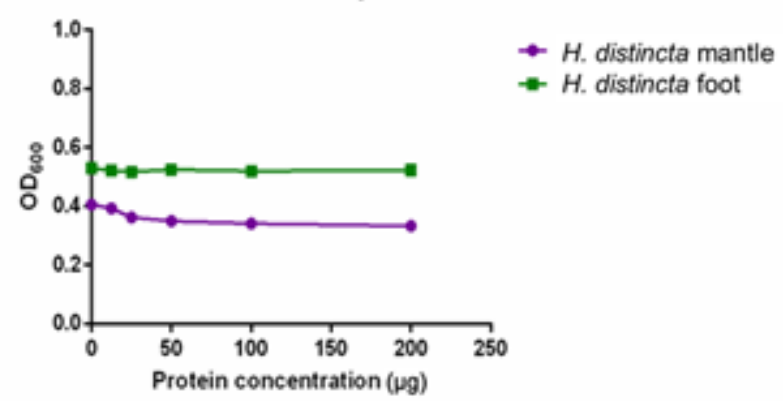

Acinetobacter sp. Y3

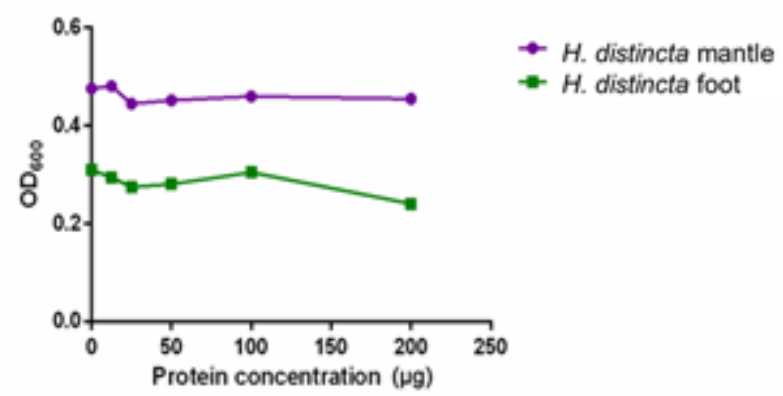

\section{Figure 3}

Antibacterial activity of $\mathrm{H}$. distincta mucus. The different protein concentrations $(12.5,25,50,100$, and $200 \mu \mathrm{g} / 100 \mu \mathrm{l}$ PBS) were incubated with E. coli, B. subtilis, S. aureus, and Acinetobacter sp. L9, PK3, and Y3 overnight and then the OD600 was determined. Data are shown as the mean \pm standard deviation, derived from three independent replicates.

\section{Supplementary Files}

This is a list of supplementary files associated with this preprint. Click to download.

- Additionalfiles1.docx

- Additionalfiles2.docx

- Additionalfiles3.docx 